\title{
Peningkatan Prestasi Belajar IPA Tema Lingkungan Sahabat Kita Melalui Penerapan Pembelajaran Kooperatif Teams Games Tournaments Berbantuan Media Teka-Teki Silang
}

\section{Endang Herlindawati ${ }^{*}$, Ny. Kusmariyatni ${ }^{2}$, Kt. Wiryawati ${ }^{3}$}

${ }^{123}$ Jurusan Pendidikan Guru Sekolah Dasar Universitas Pendidikan Ganesha

\section{A R T I C L E I N F O}

Article history:

Received January 21, 2021

Revised February 03, 2021

Accepted April 08, 2021

Available online May 25, 2021

Kata Kunci:

Teams Games Tournament,

TTS, Prestasi Belajar

Keywords:

Teams Games Tournament,

TTS, Learning Achievement

\begin{abstract}
A B S T R A K
Penelitian ini bertujuan untuk meningkatkan prestasi belajar siswa melalui penerapan model pembelajaran kooperatif tipe Teams Games Tournaments (TGT) menggunakan media Teka-Teki Silang (TTS) dalam pembelajaran IPA tema Lingkungan Sahabat Kita di Kelas V SD Negeri 3 Banjar Jawa tahun pelajaran 2018/2019. Penelitian ini menggunakan metode penelitian tindakan kelas (Classroom Action Research) yang dilaksanakan dalam tiga siklus. Subjek penelitian adalah siswa kelas VC semester II sebanyak 32 siswa. Data prestasi belajar siswa dikumpulkan setiap akhir siklus. Pengumpulan data menggunakan tes obyektif bentuk pilihan ganda. Data yang dikumpulkan dianalisis menggunakan analisis deskriptif kuantitatif yang sudah ditentukan sebelumnya. Hasil penelitian prestasi belajar siswa, pada siklus I ketuntasan klasikal sebesar 37\%, pada siklus II ketuntasan klasikal sebesar 75\%, dan pada siklus III ketuntasan klasikal prestasi belajar siswa sebesar 98,9\%. Ketuntasan klasikal prestasi belajar siswa mengalami peningkatan sebesar 38\% dan 23,9\%. Hasil penelitian menunjukkan bahwa penerapan model Teams Games Tournaments berbantuan media teka-teki silang dapat meningkatkan prestasi belajar IPA tema Lingkungan Sahabat Kita pada siswa kelas V SD Negeri 3 Banjar Jawa tahun ajaran 2018/2019.
\end{abstract}

\section{A B S TR A C T}

This study aims to improve student learning achievement through the application of the cooperative learning model of the Teams Games Tournaments type (TGT) using the crossword media (TTS) in science learning with the theme of Our Friends Environment in Class V of SD Negeri 3 Banjar Jawa 2018/2019. This study uses the class action research method (Classroom Action Research) carried out in three cycles. The research subjects were 32 students of the second semester $V C$ class. Data on student achievement were collected at the end of each cycle. Data collection used multiple choice objective tests. Data collected analyzed using quantitative descriptive analysis that has been predetermined. The results of the study of student learning achievement, in the first cycle of classical completeness by 37\%, in the second cycle of classical completeness by 75\%, and in the third cycle classical completeness students' learning achievement was $98.9 \%$. Classical completeness of student learning achievement has increased by 38\% and 23.9\%. The results of the study showed that the application of the Teams Games Tournaments model assisted with crossword puzzle media could improve the science learning achievement of the theme of the Environment of Our Friends in the fifth grade students of SD Negeri 3 Banjar Jawa in the academic year 2018/2019.

\section{Pendahuluan}

Keberhasilan pendidikan dapat ditunjukkan dari kualitas pendidikan yang ada, dimana kualitas pendidikan itu meliputi kualitas proses maupun kualitas lulusan. Jadi pendidikan dikatakan berhasil apabila proses belajar- mengajarnya berjalan dengan baik serta menghasilkan output yang berkualitas. Di dalam peningkatan mutu pendidikan perlu efisiensi pendidikan, yang mempunyai arti bahwa proses pendidikan harus mencapai hasil yang maksimal dengan biaya yang wajar. Dalam pandangan yang lebih luas efisiensi pendidikan berkaitan dengan profesionalisme dan manajemen pendidikan yang di dalamnya mengandung disiplin, kesetiaan dan etos kerja. Hal ini kurang disadari oleh para penyelenggara pendidikan yang berada di daerah pada umumnya, yang pada gilirannya mengakibatkan munculnya permasalahan pada dunia pendidikan (Maesaroh, 1970).

Pendidikan memegang peranan penting dalam mempersiapkan sumber daya manusia yang berkualitas. Oleh karena itu, pendidikan hendaknya dikelola, baik secara kualitas maupun kuantitas. Hal tersebut bisa tercapai bila pelajar dapat menyelesaikan pendidikan tepat pada waktunya dengan hasil belajar yang baik. Hasil belajar seseorang ditentukan oleh berbagai faktor yang mempengaruhinya. Salah satu faktor yang ada di luar individu adalah tersedianya bahan ajar yang memberi kemudahan bagi individu untuk mempelajarinya, sehingga menghasilkan belajar yang lebih baik. Belajar mengajar adalah 
suatu kegiatan yang bernilai edukatif. Nilai edukatif mewarnai interaksi yang terjadi antara guru dengananak didik. Interaksi yang bernilai edukatif dikarenakan kegiatan belajar mengajar yang dilakukan diarahkan untuk mencapai tujuan tertentu yang telah dirumuskan sebelum pengajaran dilakukan. Guru dengan sadar merencanakan kegiatan pembelajarannya secara sistematis dengan memanfaatkan segala sesuatunya guna kepentingan pengajaran (Rahmayanti, 2016)

Pendidikan merupakan suatu proses yang diperlukan untuk mendapatkan keseimbangan dan kesempurnaan dalam perkembangan individu maupun masyarakat. Penekanan pendidikan dibanding dengan pengajaran terletak pada pembentukan kesadaran dan kepribadian individu atau masyarakat di samping transfer ilmu dan keahlian. Dengan proses semacam ini suatu bangsa atau negara dapat mewariskan nilai-nilai keagamaan, kebudayaan, pemikiran dan keahlian kepada generasi berikutnya, sehingga mereka betul-betul siap menyongsong masa depan kehidupan bangsa dan negara yang lebih cerah. Pendidikan juga merupakan sebuah aktifitas yang memiliki maksud atau tujuan tertentu yang diarahkan untuk mengembangkan potensi yang dimiliki manusia baik sebagai manusia ataupun sebagai masyarakat dengan sepenuhnya (Nurkholis, 2013).

Pendidikan juga merupakan kegiatan yang kompleks, dan meliputi berbagai komponen yang berkaitan erat satu sama lain. Oleh sebab itu, apabila pendidikan ingin dilaksanakan secara terencana dan teratur, maka berbagai faktor yang terlibat dalam pendidikan harus dipahami terlebih dahulu. Berbagai komponen dalam sistem pendidikan, baik secara mikro maupun dalam kajian makro perlu dikenali secara mendalam sehingga komponen-komponen tersebut dapat difungsikan dan dikembangkan guna mengoptimalkan garapan pendidikan tersebut ke arah pencapaian tujuan pendidikan yang ditetapkan (Arsyad, 2016).

Belajar merupakan proses internal yang kompleks. Yang terlibat dalam proses internal tersebut adalah seluruh mental yang meliputi ranah-ranah kognitif, afektif dan ranah psikomotorik. Proses belajar yang mengaktualisasikan ketiga ranah tersebut tertuju pada bahan belajar tertentu. Sebagai landasan penguraian mengenai apa yang dimaksud dengan belajar terlebih dahulu akan dikemukan definisi belajar baik menurut pandangan psikologi maupun dalam pandangan agama. Dalam perspektif psikologi, belajar adalah merupakan proses dasar dari perkembangan hidup manusia. Dengan belajar, manusia melakukan perubahan-perubahan kualitatif individu sehingga tingkah lakunya berkembang. Semua aktivitas dan prestasi hidup manusia tidak lain adalah hasil dari belajar. Belajar itu bukan sekedar pengalaman, belajar berlangsung secara aktif dan integratif dengan berbagai bentuk perbuatan untuk mencapai suatu tujuan. Sementara pengertian belajar dalam perspektif agama yaitu Islam, belajar merupakan kewajiban bagi setiap muslim dan muslimah dalam rangka memperoleh ilmu pengetahuan sehingga derajat hidupnya meningkat. Pernyataan ini dipertegas lagi dengan beberapa firman Allah Swt dalam surat al-Mujadalah: 11, surat al- 'Alaq: 1-5 dan surat al-Muddatstsir: 74. Ketiga ayat ini merupakan dasar konsep aktivitas belajar dan merupakan dasar konsep belajar yang ideal (Nidawati, 2013).

Robbins dan Judge (2007) menjelaskan motivasi berkenaan dengan intensitas, arah dan ketekunan usaha untuk mencapai suatu tujuan. Motivasi juga sebagai dorongan (driving force) untuk mencapai sesuatu. Maka untuk pembahasan lebih jauh artikel ini mencoba untuk menjelaskan bagaimana dapat motivasi memberikan pengaruh belajar kepada seseorang, atau dengan kata lain bagaimana pengaruh motivasi terhadap belajar seseorang (Marisa, 2019). Motivasi dan belajar adalah dua hal yang tidak dapat dipisahkan. Dalam kegiatan belajar diperlukan motivasi yang mendukung belajar siswa. Belajar yang dilandasi oleh motivasi yang kuat akan memberikan hasil belajar yang lebih baik.Sebagaimana diketahui belajar adalah proses orang memperoleh berbagai kecakapan, ketrampilan dan sikap. Belajar membawa perubahan perilaku. Perubahan tersebut bukan dalam arti perubahan dari segi kelelehan fisik, penggunaan akibat obat, penyakit parah atau trauma fisik ataupun pertumbuhan jasmani. Tetapi berupa perubahan tingkah laku yang secara relatig permanen dan secara potensial terjadi sebagai hasil usaha belajar. Slameto menjelaskan bahwa dalam kegiatan belajar, usaha belajar yang mengantark kepada perubahan tingkah laku adalah, dalam hal menerima pelajaran secara tuntas, menyelesaikan tugas-tugas pelajaran dan mempelajari buku-buku yang menunjang, mengingat-ingat apa yang sudah dipelajari dan menghubungkan informasi belajar yang baru diperoleh terhadap struktur kognitif yang sudah ada dalam ingatannya serta menghubungkan apa yang sudah diketahuinya dengan pekerjaan di lapangan (Maryam, 2016).

Ilmu pengetahuan alam (IPA) merupakan ilmu yang mempelajari tentang gejala alam berupa fakta, konsep dan hukum yang telah teruji kebenarannya melalui suatu rangkaian penelitian. Pembelajaran IPA diharapkan dapat membantu siswa untuk memahami fenomena-fenomena alam. Berdasarkan karakteristiknya, pembelajaran IPA dapat dipandang dari dua sisi, yaitu pembelajaran IPA sebagai suatu produk hasil kerja ilmuwan dan pembelajaran IPA sebagai suatu proses sebagaimana ilmuwan bekerja agar menghasilkan ilmu pengetahuan (Waldrip dkk., 2010; Tala dan Vesterinen, 2015). Pandangan IPA sebagai produk hasil kerja ilmuwan, dalam proses pembelajarannya dilakukan dengan memberitahukan 
kepada siswa tentang konsep, hukum, teori dan fakta tentang ilmu pengetahuan alam, tanpa memberikan kesempatan kepada siswa untuk mendapatkan dan mengkonstruksi konsep sendiri. Proses pembelajaran tersebut biasanya dilakukan dengan ceramah. Pembelajaran yang dilakukan dengan ceramah, membuat siswa sebagai objek pasif yang menerima pengetahuan saja (Fitriyati, Hidayat and Munzil, 2017).

Kurikulum 2013 mengubah proses pembelajaran yang berpusat pada guru menjadi berpusat pada siswa sehingga peserta didik menjadi lebih aktif. Pembelajaran yang sesuai dengan kurikulum 2013 adalah pembelajaran yang menggunakan pendekatan saintifik dengan tahapan 5M, yaitu mengamati, menanya, mengumpulkan informasi, mengasosiasi, dan mengomunikasikan. Pelaksanaan pembelajaran pada kurikulum 2013, guru dituntut untuk menciptakan suasana pembelajaran yang menyenangkan dengan menggunakan berbagai model pembelajaran maupun media pembelajaran yang tepat dan efektif. Pemilihan model pembelajaran yang tepat akan berpengaruh terhadap prestasi belajar yang dicapai peserta didik. Dalam hal ini guru harus mampu memilih model pembelajaran yang sesuai dengan proses pembelajaran yang akan dilaksanakan.

Proses pembelajaran akan lebih bermakna jika guru dapat menyajikan pembelajaran yang menyenangkan dan interaktif. Penyajian pembelajaran dapat menyenangkan apabila dapat melibatkan siswa secara aktif dengan model pembelajaran dan media yang sesuai. Hal ini sesuai dengan Permendikbud Nomor 22 Tahun 2016 bahwa proses pembelajaran pada satuan pendidikan diselenggarakan secara interaktif, inspiratif, menyenangkan, menantang, memotivasi peserta didik untuk berpartisipasi aktif, serta memberikan ruang yang cukup bagi prakarsa, kreativitas, dan kemandirian sesuai dengan bakat, minat, dan perkembangan fisik serta psikologi peserta didik.

Model pembelajaran kooperatif menyediakan alternatif dalam pembelajaran dan menawarkan berbagai cara untuk meningkatkan aktivitas maupun prestasi belajar peserta didik. Salah satu model pembelajaran kooperatif yang memungkinkan siswa secara interaktif, efektif, dan menyenangkan yaitu Teams Games Tournament (TGT) yang mendorong peserta didik bermain sambil berpikir dalam kelompok dan berkompetisi antar kelompok. Dengan adanya permainan, pembelajaran akan lebih menyenangkan karena usia sekolah dasar adalah usia anak senang bermain.

Penerapan model pembelajaran TGT menuntut kreativitas guru, terlebih jika diterapkan pada sekolah dasar sehingga proses pembelajaran berlangsung secara efektif dan berhasil dengan baik. Dalam hal ini, keberhasilan implementasi kurikulum 2013 dalam kegiatan pembelajaran di sekolah dasar sesuai dengan pemerintah dan masyarakat, sangat ditentukan oleh guru. Guru harus mempunyai pemahaman, kesadaran, kemampuan, kreativitas, kesabaran dan keuletan dalam melaksanakan proses pembelajaran di kelas.

Kondisi di lapangan ternyata peserta didik seringkali menunjukkan sikap kurang antusias dalam pembelajaran yang menuntut siswa memahami konsep materi yang luas melalui ceramah guru, seperti muatan IPA dalam kurikulum 2013. Hal tersebut membuat peserta didik kurang aktif dan menunjukkan rasa bosan dengan tidak memperhatikan guru ketika menjelaskan, ramai sendiri dengan teman bahkan ada yang mengantuk ketika proses pembelajaran berlangsung. Saat proses pembelajaran berlangsung, peserta didik tampak tidak bersemangat dan sulit berinteraksi baik dengan guru maupun dengan peserta didik lain. Keaktifan peserta didik yang rendah dalam proses pembelajaran akan berdampak pada rendahnya prestasi belajar peserta didik.

Berdasarkan uraian latar belakang tersebut, dapat diidentifikasikan beberapa masalah. Masalah tersebut yaitu kurangnya antusias peserta didik dalam proses pembelajaran terutama pada muatan IPA, pembelajaran yang cenderung menggunakan metode ceramah yang membuat lingkungan belajar membosankan dan menjadikan peserta didik kurang aktif, kurangnya kreativitas guru dalam menggunakan model pembelajaran, yang dapat mempengaruhi prestasi belajar peserta didik terutama dalam kompetensi pengetahuan IPA.

Berdasarkan uraian latar belakang di atas, maka peneliti ingin melakukan penelitian tindakan kelas yang mampu meningkatkan prestasi belajar peserta didik dengan tetap menggunakan pendekatan saintifik 5M dengan permainan Teka-teki Silang. Penelitian tersebut tentang penerapan model pembelajaran kooperatif tipe TGT (Teams Games Tournament) yang dipadukan dengan media Teka-Teki Silang untuk meningkatkan prestasi belajar peserta didik. Dengan media TTS dalam metode games dapat meningkatkan antusias siswa dalam proses pemebelajaran. Siswa harus menemukan strategi yang dalam menjawab TTS dengan mengisi setiap kolom dengan huruf yang tepat. Hal ini dapat merangsang siswa berpikir aktif dan kreatif serta bertanggung jawab dengan jawabannya karena akan mempengaruhi skor kelompoknya.

Dalam penelitian ini dibatasi hanya memecahkan masalah rendahnya prestasi belajar ranah pengetahuan pada siswa kelas V tema Lingkungan Sahabat Kita SD Negeri 3 Banjar Jawa tahun pelajaran $2018 / 2019$. 


\section{Metode}

Penelitian ini merupakan penelitian tindakan kelas (Classroom Action Research) yang dilaksanakan dalam tiga siklus, dengan tiap siklusnya terdiri dari perencanaan, pelaksanaan, observasi, dan refleksi. Rancangan yang dimaksud adalah tindakan berupa penerapan model pembelajaran TGT berbantuan media TTS.

Subjek penelitian adalah siswa kelas VC SD Negeri 3 Banjar Jawa tahun pelajaran 2018/2019, Buleleng, Bali, yang berjumlah 32 siswa. Objek penelitian ini adalah prestasi belajar tema Lingkungan Sahabat Kita ranah pengetahuan muatan pelajaran IPA.

Metode pengumpulan data yang digunakan adalah dengan tes berupa soal pilihan ganda untuk mengukur prestasi belajar IPA ranah pengetahuan. Data mengenai hasil prestasi belajar IPA diperoleh dengan menggunakan tes soal evaluasi yang dilaksanakan pada setiap akhir siklus. Tes terdiri dari 10 soal pilihan ganda.

Analisis data yang digunakan yaitu analisis deskriptif secara presentase terhadap data yang diperoleh dari hasil lembar evaluasi yang dikerjakan siswa. Analisis data ini melalui tiga tahap yaitu menentukan ketuntatasan individu. KKM yang ditentukan adalah 70 . Siswa dikatakan tuntas apabila mendapat nilai individu $>=70$. Kemudian menghitung rata-rata nilai kelas dan dilanjutkan dengan mengukur presentase ketuntasan klasikal. Keberhasilan dalam penelitian ini yaitu apabila presentase ketuntasan klasikal mencapai 85\%.

\section{Hasil Dan Pembahasan}

Nilai Data yang diperoleh dalam penelitian ini adalah prestasi belajar siswa. Prestasi belajar yaitu aspek pengetahuan. Dalam penelitian ini digunakan tes pengetahuan yang diberikan setiap akhir siklus.

\section{Hasil Tindakan Siklus I}

Peneliti mengkaji silabus lalu berdasarkan silabus peneliti membuat rencana pembelajaran. Pembelajaran didesain dengan menggunakan model kooperatif Teams Games Tournaments (TGT) dilengkapi teka-teki silang. Instrumen yang digunakan sebagai alat evaluasi adala soal tes aspek pengetahuan yang telah diujicobakan untuk mengetahui kelayakannya sebagai alat evaluasi.

Kegiatan pembelajaran yang telah direncanakan oleh peneliti seperti yang tercantum dalam RPP. Kegiatan pembelajaran dalam RPP kemudian diterapkan di kelas VC SD Negeri 3 Banjar Jawa tahun pelajaran 2018/2019.

Ketercapaian siklus I disajikan dalam tabel berikut.

Tabel 1. Hasil Siklus I

\begin{tabular}{ccc}
\hline Aspek & Rata-Rata & Ketuntasan Klasikal \\
\hline Pengetahuan & 70,6 & $37 \%$ \\
\hline
\end{tabular}

Dari tabel 1 menunjukkan bahwa rata-rata prestasi belajar siswa sudah memenuhi KKM 70. Sedangkan capaian ketuntasan klasikal 37\% yaitu terdapat 12 siswa yang tuntas dan ketuntasan klasikal tersebut belum mencapai target yang diharapkan yaitu $85 \%$.

\section{Refleksi Siklus I}

Dari hasil siklus I di atas dapat diketahui bahwa prestasi belajar ranah pengetahuan siswa secara klasikal belum mencapai target. Oleh karena itu perlu dilakukan perbaikan pada siklus II. Selain mengupayakan peningkatan prestasi belajar pengetahuan siswa, tindakan pada siklus II bertujuan untuk meningkatkan rata-rata dan meningkatkan ketercapaian ketuntasan klasikal yang telah dicapai pada siklus I.

2. Hasil Tindakan Siklus II

Berdasarkan hasil refleksi siklus I maka dilakukan perencanaan pelaksanaan tindakan pada siklus II. Materi yang diberikan difokuskan pada indikator yang belum tuntas pada siklus I. Tindakan pada siklus II lebih difokuskan untuk penyempurnaan dan perbaikan terhadap kendala-kendala yang terdapat pada siklus I.

Seperti pembelajaran pada siklus I, guru menerapkan model pembelajaran TGT berbantuan tekateki silang dalam proses pembelajaran.

Ketercapaian siklus II disajikan dalam tabel berikut.

Tabel 2. Hasil Siklus II

\begin{tabular}{ccc}
\hline Aspek & Rata-Rata & Ketuntasan Klasikal \\
\hline Pengetahuan & 72,2 & $75 \%$ \\
\hline
\end{tabular}


Dari tabel 2 menunjukkan bahwa rata-rata prestasi belajar siswa sudah memenuhi KKM 70. Sedangkan capaian ketuntasan klasikal 75\% yaitu terdapat 24 siswa yang tuntas. Meskipun sudah banyak siswa yang tuntas, tapi ketuntasan klasikal tersebut belum mencapai target yang diharapkan yaitu $85 \%$.

3. Refleski Siklus II

Dari hasil siklus II di atas dapat diketahui bahwa prestasi belajar ranah pengetahuan siswa secara klasikal belum mencapai target. Oleh karena itu perlu dilakukan perbaikan pada siklus III. Selain mengupayakan peningkatan prestasi belajar pengetahuan siswa, tindakan pada siklus III bertujuan untuk meningkatkan rata-rata dan meningkatkan ketercapaian ketuntasan klasikal yang telah dicapai pada siklus II

4. Hasil Tindakan Siklus III

Berdasarkan hasil refleksi siklus II maka dilakukan perencanaan pelaksanaan tindakan pada siklus III. Kegiatan yang diberikan difokuskan pada pendalaman materi yang sudah dilakukan pada siklus I dan II. Tindakan pada siklus III lebih difokuskan untuk pencapaian target dan penyempurnaan terhadap kendala-kendala yang masih terdapat pada siklus II.

Seperti pembelajaran pada siklus II, guru menerapkan model pembelajaran TGT berbantuan tekateki silang dalam proses pembelajaran.

Ketercapaian siklus II disajikan dalam tabel berikut.

Tabel 3. Hasil Siklus III

\begin{tabular}{ccc}
\multicolumn{1}{c}{ Aspek } & Rata-Rata & Ketuntasan Klasikal \\
\hline Pengetahuan & 78,1 & $98,9 \%$ \\
\hline
\end{tabular}

Dalam penelitian ini target ketuntasan klasikal yaitu 85\%. Berdasarkan tabel 3, dapat diketahui bahwa presentase ketuntasan klasikal meningkat, dari siklus II 75\% dan pada siklus III mengalami peningkatan menjadi 98,9\% atau dapat dikatakan 31 siswa sudah tuntas mencapai nilai KKM. Begitu juga dengan nilai rata-rata meningkat menjadi 78,1.

\section{Refleksi Siklus III}

Dari hasil target ketercapaian pada siklus III diketahui bahwa aspek prestasi belajar pengetahuan siswa yang disajikan mencapai target yang ditentukan.

Sehingga dapat disimpulkan bahwa pembelajaran tema Lingkungan Sahabat Kita dengan menerapkan model pembelajaran Teams Games Tournaments (TGT) berbantuan TTS telah berhasil.

Pembelajaran dengan menerapkan model pembelajaran Teams Games Tournaments (TGT) berbantuan TTS, terjadi peningkatan hasil dari siklus I sampai siklus III. Hasil tindakan dari tiga siklus disajikan sebagai berikut.

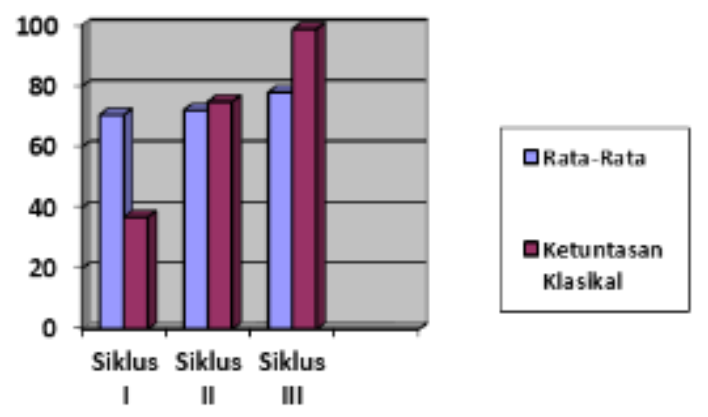

Gambar 1. Histogram Rata-Rata dan Ketuntasan Klasikal Siklus I, II, III

Penggunaan model Teams Games Tournemants berbantuan media teka-teki silang dapat meningkatkan prestasi belajar IPA kelas VC Tema Lingkungan Sahabat Kita, hal ini dapat dilihat dari peningkatan nilai siswa setiap siklusnya. Rata-rata prestasi belajar siswa pada siklus I yaitu 70,6 dengan presentase ketuntasan belajar klasikal siswa adalah 37\%. Pada siklus II rata-rata prestasi belajar IPA siswa yaitu 72,2 dengan presentase ketuntasan belajar klasikal siswa adalah 75\%. Pada siklus III rata-rata prestasi belajar IPA siswa yaitu 78,1 dengan presentase ketuntasan belajar klasikal siswa adalah 98,9\%. Presentase tingkat prestasi belajar IPA siswa dari siklus I ke siklus II mengalami peningkatan rata-rata 1,6\%. Presentase tingkat prestasi belajar IPA siswa dari siklus II ke siklus III mengalami peningkatan ratarata $5,9 \%$. 
Berdasarkan hasil penelitian di atas dapat disimpulkan bahwa Penerapan Model pembelajaran kooperatif tipe Teams Games Tournament (TGT) berbantuan media teka-teki silang dapat meningkatkan prestasi belajar IPA siswa kelas V SD Negeri 3 Banjar Jawa tahun ajaran 2018/2019 dengan ketuntasan klasikal mencapai minimal 85\% . Seperti yang dikemukakan oleh E.Mulyasa (2008: 256) bahwa pembelajaran dikatakan berhasil dan berkualitas jika seluruhnya atau setidak-tidaknya sebagian besar (75\%) peserta didik terlibat secara aktif, baik fisik, mental maupun sosial dalam pembelajaran.

\section{Simpulan}

Berdasarkan hasil penelitian, maka dapat disimpulkan bahwa penerapan pembelajaran kooperatif Teams Games Tournaments (TGT) berbantuan media teka-teki silang dapat meningkatkan prestasi belajar IPA tema Lingkungan Sahabat Kita siswa kelas V SD Negeri 3 Banjar Jawa tahun ajaran 2018/2019. Hal tersebut dapat dibuktikan dengan adanya peningkatan presentase rata-rata hasil belajar yang diambi melalui tes evaluasi setiap akhir siklus. Rata-rata siklus I yaitu 70,6 dengan ketuntasan klasikal mencapai $37 \%$, rata-rata pada siklus II yaitu 72,2 dengan ketuntasan klasikal mencapai $75 \%$, dan pada siklus III rata-rata 78,1 dengan ketuntasan klasikal mencapai 98,9\%. Dengan demikian ketuntasan klasikal siswa dari siklus I sampai siklus III mengalami peningkatan sebesar 61,9\%.

Berdasarkan hasil temuan pada penelitian tindakan kelas, beberapa saran yang dapat dikemukakan berkaitan dengan pembelajaran yaitu bagi siswa hendaknya belajar dengan cara yang beragam, bukan hanya terpaku pada penjelasan yang disampaikan oleh guru. Siswa hendaknya belajar dengan aktif mengeluarkan pendapat, mencari informasi dari berbagai sumber kemudian mengemukakan pendapatnya sehingga siswa dapat menalar dan berkolaborasi dengan kelompoknya. Bagi guru agar lebih kreatif dalam menerapkan strategi pembelajaran. Salah satu alternatif mengajar adalah dengan menggunakan model Teams Games Tournaments (TGT) dengan menggunakan media teka-teki silang. Guru diharapkan kreatif dalam membuat TTS dan lebih kreatif menciptakan suasana belajar yang semangat dengan adanya turnamen. Dalam penerapannya guru hendaknya menjadi motivator, fasilitator dan membimbing siswa dalam diskusi dengan kelompoknya. Bagi sekolah diharapkan selalu tanggap terhadap berbagai inovasi pembelajaran, baik model maupun media pembelajaran yang digunakan dalam kegiatan pembelajaran sehingga dapat meningkatkan prestasi dan mutu sekolah.

\section{Daftar Pustaka}

Arsyad, A. (2016) 'Jurnal Dimensi Pendidikan Dan Pembelajaran Vol.5 Januari 2016 | 29', Jurnal Dimensi Penididikan Dan Pembelajaran, 5, Pp. 29-37.

Fitriyati, I., Hidayat, A. And Munzil (2017) 'Pengembangan Perangkat Pembelajaran Ipa Untuk Meningkatkan Kemampuan Berpikir Tingkat Tinggi Dan Penalaran Ilmiah Siswa Sekolah Menengah Pertama', Jurnal Pembelajaran Sains, 1(1), Pp. 27-34.

Maesaroh, S. (1970) 'Peranan Metode Pembelajaran Terhadap Minat Dan Prestasi Belajar Pendidikan Agama Islam', Jurnal Kependidikan, 1(1), Pp. 150-168. Doi: 10.24090/Jk.V1i1.536.

Marisa, S. (2019) 'Pengaruh Motivasi Dalam Pembelajaran Siswa Upaya Mengatasi Permaslahan Belajar', Jurnal Taushiah, $9(2)$, Pp. 20-27. Available At: Https://Jurnal.Uisu.Ac.Id/Index.Php/Tsh/Article/View/1786.

Maryam, M. (2016) 'Pengaruh Motivasi Dalam Pembelajaran', Lantanida Journal, 4(2), Pp. 88-97. Available At:Https://Jurnal.Arraniry.Ac.Id/Index.Php/Lantanida/Article/Download/1881/1402\%0ahttps:// Media.Neliti.Com/Media/Publications/287678-Pengaruh-Motivasi-Dalam-PembelajaranDc0dd462.Pdf.

Nidawati (2013) 'Belajar Dalam Perspektif Psikologi Dan Agama', Journal Of Chemical Information And Modeling, 53(9), Pp. 1689-1699.

Nurkholis (2013) 'Pendidikan Dalam Upaya Memajukan Teknologi Oleh: Nurkholis Doktor Ilmu Pendidikan, Alumnus Universitas Negeri Jakarta Dosen Luar Biasa Jurusan Tarbiyah Stain Purwokerto', 1(1), Pp. 24-44.

Rahmayanti, V. (2016) 'Pengaruh Minat Belajar Siswa Dan Persepsi Atas Upaya Guru Dalam Memotivasi Belajar Siswa Terhadap Prestasi Belajar Bahasa Indonesia Siswa Smp Di Depok', Sap (Susunan Artikel Pendidikan), 1(2), Pp. 206-216. Doi: 10.30998/Sap.V1i2.1027. 